\title{
Kelet-Közép-Európa az autóipar nemzetközi munkamegosztásában
}

\section{Eastern Europe in the international division of labour of the automotive industry}

\author{
MOLNÁR ERNŐ
}

KULCSSZAVAK: autóipar, Kelet-Közép-Európa, nemzetközi munkamegosztás

\begin{abstract}
ABSZTRAKT: Kelet-Közép-Európa az autóipar egyik kitüntetett beruházási terepének számít. A tanulmány a térségnek az iparágban játszott szerepét vizsgálja, külkereskedelmi adatok tükrében. Az autóipar térszerkezetében és nemzetközi munkamegosztásában mutatkozó változásoknak a szakirodalomra épített rövid összegzése után elemzi a régió iparági kereskedelembe kapcsolódásának mikéntjét, gépjármúgyártásának területi kapcsolatrendszerét és kivitelének termékszerkezetét. A vizsgálat az ezredforduló utáni évtizedre fókuszál, középpontjában az autóipar beruházásai által leginkább érintett visegrádi országok, továbbá Románia és Szlovénia állnak.
\end{abstract}

KEYWORDS: automotive industry, Central-Eastern Europe, international division of labour

ABSTRACT: The study is based on international trade data and focuses on the role of Eastern Europe in the global automotive industry. After summarising the results of a literature research about the actual changes in territorial structure and international division of labour within the automotive industry, the study analyses how this region is integrated in the trade of this sector and which geographical structure and product range the regional automotive export shows. The research deals with the processes in the decade after the turn of the Millenium and concentrates on the Visegrad countries (Poland, the Czech Republic, Slovakia, Hungary) as well as Romania and Slovenia, which play important roles in European investments regarding this industry.

The analysis shows that Eastern Europe became an increasingly important and export-oriented production site of this sector dominated by transnational companies. The automotive industry of the region functions as a part of the European production and consumption system and has intensive connections first of all with Germany. The growing importance of car components in the export structure signifies a deepening of the intra-firm industrial division of labour, which is most typical for the German car industry and for the automotive trade within the region. Eastern Europe - the "backyard" of Germany - moved closer to being an automotive region during the last decade.

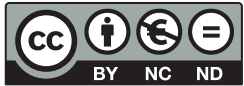




\section{Az autóipar térszerkezetének és területi munkamegosztásának változása}

$\mathrm{Az}$ autóipar jelentös térbeli expanziót, komoly földrajzi súlyponteltolódást mutatott az utóbbi évtizedekben. Területi dinamikáját általában a fogyasztás és a termelés helyi feltételeivel, valamint a két tényezőt közvetlenül vagy közvetett módon befolyásoló politikai-intézményi keretfeltételekkel magyarázzák (Humphrey, Memedovic 2003, Dicken 2011). Napjaink egyik leginkább feltűnő jelensége a regionális gazdasági integrációk (EU, NAFTA) perifériáinak autóipari telephelyként történő felértékelödése. E területek népszerüsége - az iparágban domináns szerepet játszó transznacionális szereplők körében - elsősorban a termelés szempontjából kedvezö telephelyi adottságaikkal indokolható. Az érintett országok vezető autópiacok közelében helyezkednek el, politikailag stabil és költséghatékony telephelyeket kínálnak, jelentős ipari kultúrával rendelkeznek, kormányzataik az általánosan alkalmazott exportorientált növekedési modell jegyében - a jelentős multiplikátor-hatásokkal rendelkező autóipar által generált munkahelyteremtés és technológiai modernizáció reményében különböző eszközökkel támogatják az iparág megtelepülését (Radosevic, Rozeik 2005, Schamp 2005, Kemenczei, Nikodémus 2006, Jürgens, Krzywdzinski 2009, Molnár 2009).

Az autóipar térszerkezeti változásai, illetve területi munkamegosztása kapcsán három meghatározó tendencia körvonalazható a szakirodalom alapján. Egyrészt, a termelés szempontjából költséghatékony telephelyek felértékelödése az autóipari termelés és fogyasztás növekvö mértékü területi szétválását eredményezi. Másrészt - bár az autóipari értékláncokon belül a meghatározó K+F-tevékenységek és egyes bonyolult alkatrészek előállítása általában globálisan szerveződik -, az iparág termelésére az autóipari termékek kereskedelmét meghatározó nemzetközi körülmények következtében (Európában) regionális (kontinentális) integrációs keretek jellemzőek. Harmadrészt, az autóipari értékláncok különböző elemeinek térbeli mobilitása eltérő mértékű: a termelés növekvő földrajzi dezintegrációja, az iparágon/vállalaton belüli nemzetközi kereskedelem intenzív fejlődése figyelhető meg. Az elmélyülő területi munkamegosztásban az értékláncok egyes elemei a számukra fontos telepítőtényezőknek megfelelően - a méretgazdaságosság szempontjait is érvényesítve - települnek, az autóipar térben aránytalan fejlődését, egyes telephelyek bizonyos értékteremtési lépésekre történő specializálódását eredményezve (Humphrey, Memedovic 2003, Sturgeon, T., Van Biesebroeck, J., Gereffi, G. 2008).

A jelen cikkben bemutatott vizsgálatok a Nemzetközi Kereskedelmi Központ (International Trade Centre) interneten hozzáférhető külkereskedelmi adatbázisára épülnek. Az autóiparra fókuszáló elemzés alapját a közúti jármügyártás adatai képezték, amelyek a legváltozatosabb gépjármütípusok (személygépkocsik, buszok, tehergépjárművek, motorkerékpárok) mellett a gépjárműalkatrészek és a 
nem géperejű közúti járművek statisztikáit is magukba foglalják. Az adatok e körülmények ellenére is relevánsnak tekinthetőek kutatott témánk szempontjából, hiszen a gépjármü- és gépjárműalkatrész-gyártás adja a termékcsoport forgalmának túlnyomó részét. Fontos azonban megjegyezni, hogy e statisztikák nem tükrözik maximálisan az autóiparnak a külkereskedelemben játszott tényleges szerepét. Egyrészt, a beszállító iparágak nem minden autóiparhoz kötődő exportteljesítménye (bőr-, gumi- vagy üvegipari termékek, elektronikai alkatrészek) jelenik meg a közúti járműgyártás adataiban, és ez a valóságosnál kisebbnek mutatja az iparág jelentőségét. Másrészt, az autóipari export nyers értékei elfedik a kiszállított értékben rejlő helyi hozzáadott érték különbségeit, s így túlértékelik a komolyabb helyi beszállítói háttérrel nem rendelkező, erős importvonzattal bíró tevékenységeket.

A továbbiakban négy hipotézis valóságtartalmát vizsgálja a tanulmány. (1) Az első feltételezés szerint Kelet-Közép-Európa mindinkább a globális autóipar egyik termelőbázisa, növekvő exportorientáltságú gépjárműgyártó országokkal. (2) Második hipotézisem szerint a térség autóipara az európai kontinens regionális termelési és fogyasztási rendszerébe ágyazódik, külgazdasági kapcsolatrendszerében meghatározó szerepe van azoknak az európai országoknak (elsősorban Németországnak), ahonnan a beruházó autóipari cégek érkeztek. (3) Harmadik feltételezésem szerint Kelet-Közép-Európa egy elmélyülő iparágon/vállalaton belüli nemzetközi munkamegosztás szereplője, kivitelében - a késztermékekkel szemben - nagy, illetve növekvő jelentősége van a gépjárműalkatrész-exportnak. (4) Végül, negyedik hipotézisem szerint - feltételezve az iparág kritikus tömegének kialakulását, a régió országai között komoly iparági kapcsolatok meglétét, valamint e kapcsolatok iparágon/vállalaton belüli gépjárműalkatrész-kereskedelem formájában történő megerősödését - Kelet-Közép-Európa területén mindinkább egy egységes autóipari körzet van formálódóban.

\section{Kelet-Közép-Európa exportorientált autóipara}

Kelet-Közép-Európa vizsgált országainak (a továbbiakban: Hatok, KKE-6) autóipari exportja látványosan növekedett 2001 és 2008 között, majd az iparágat sújtó recesszió hatására produkált némi visszaesést, hogy 2010-ben ismét megközelítse a válság előtti szintet. A növekedés, majd a világátlagtól elmaradó mértékủ visszaesés hatására felértékeloodött a térség a világ és Európa autóiparában, az egyes országok eltérő dinamikája nyomán pedig módosultak a régión belüli erőviszonyok. A térség legnagyobb autóipari exportőre az évtized nagyobb részében Csehország (1. táblázat). 2010-ben Csehország és Románia autóipari kivitelének értéke nagyobb volt, mint korábban bármikor, Csehország, Lengyelország és Szlovákia egyaránt a világ húsz legjelentősebb autóipari exportőre közé került. 
1. táblázat: A Hatok autóipari kivitele a világ iparági exportjának százalékában, és összesített részesedése az Európai Unió autóipari exportjából

Automotive export of CEE countries (in percentage of the worldwide automotive export) and their summerized share (\%) of the automotive export of EU

\begin{tabular}{lcccrrrr}
\hline $\begin{array}{c}\text { Ország } \\
\text { (a viszonyítás alapja) }\end{array}$ & 2001 & 2003 & 2005 & 2007 & 2008 & 2009 & 2010 \\
\hline Csehország & 0,96 & 1,05 & 1,40 & 1,72 & 1,87 & 2,31 & 2,11 \\
Lengyelország & 0,59 & 0,75 & 1,28 & 1,59 & 2,00 & 2,39 & 1,94 \\
Magyarország & 0,49 & 0,50 & 0,56 & 0,88 & 1,00 & 0,90 & 0,82 \\
Románia & 0,04 & 0,07 & 0,15 & 0,28 & 0,33 & 0,58 & 0,57 \\
Szlovákia & 0,43 & 0,85 & 0,64 & 1,15 & 1,25 & 1,30 & 1,23 \\
Szlovénia & 0,19 & 0,21 & 0,30 & 0,36 & 0,35 & 0,41 & 0,32 \\
\hline KKE-6 (a világ) & 2,70 & 3,42 & 4,33 & 5,98 & 6,80 & 7,89 & 6,99 \\
KKE-6 (az EU) & 5,33 & 6,35 & 8,26 & 11,39 & 13,01 & 14,80 & 14,11 \\
\hline
\end{tabular}

Forrás: ITC

A Hatok exportszerkezetében már az ezredfordulón is jelentős szerepet játszott az iparág, és súlya az évtized folyamán - országonként eltérő mértékben - tovább gyarapodott. Különösen látványos volt előretörése Románia exportjában: keleti szomszédunk kivitelében - a XXI. század első évtizedében - a közúti jármügyártás a 12. helyről a 2. helyre lépett előre. Az autóipari termékek aránya Szlovákia exportjában volt a legnagyobb (2. táblázat). Jelentős súlya ellenére sem beszélhetünk az autóiparnak a régió kivitelében játszott egyértelmü vezető szerepéröl, hiszen az iparág 2010-ben csak Lengyelországban és Szlovéniában számított a legnagyobb exportőrnek (az elektronikai ipar és a gépgyártás mellett ugyanakkor minden vizsgált országban az első három külföldi értékesítő között szerepelt).

Kelet-Közép-Európa már az ezredfordulón is külkereskedelmi többletet regisztrált a vizsgált iparágban, amelynek értéke az évtized folyamán összességében tovább növekedett, és számottevő mértékben meghaladta az

2. táblázat: A Hatok, az Európai Unió, illetve a világ országainak autóipari kivitele,

összes exportjuk százalékában

Automotive export of CEE countries, the European Union and the world, in percentage of their total exports of goods

\begin{tabular}{|c|c|c|c|c|c|c|c|}
\hline Ország, terület & 2001 & 2003 & 2005 & 2007 & 2008 & 2009 & 2010 \\
\hline Csehország & 16,0 & 15,3 & 16,4 & 16,8 & 15,9 & 17,3 & 17,2 \\
\hline Lengyelország & 9,2 & 10,1 & 13,0 & 13,5 & 14,4 & 14,8 & 13,4 \\
\hline Magyarország & 8,9 & 8,2 & 8,3 & 11,0 & 11,4 & 9,2 & 9,4 \\
\hline Románia & 2,2 & 2,8 & 4,8 & 8,1 & 8,3 & 12,2 & 12,4 \\
\hline Szlovákia & 18,8 & 27,7 & 18,2 & 23,5 & 22,0 & 19,8 & 20,4 \\
\hline Szlovénia & 11,6 & 11,5 & 15,3 & 16,2 & 14,7 & 15,7 & 14,2 \\
\hline$\overline{K K E-6}$ & 71,3 & 12,4 & 12,8 & 74,8 & 74,7 & 74,8 & 74,4 \\
\hline$E U-27$ & 71,6 & 12,5 & 12,0 & 71,8 & 17,2 & 10,1 & 10,4 \\
\hline Világ & 9,1 & 9,5 & 8,8 & 8,5 & 7,8 & 6,9 & 7,4 \\
\hline
\end{tabular}

Forrás: ITC 
3. táblázat: A Hatok, illetve az Európai Unió autóipari külkereskedelmének egyenlege, összes iparági termékforgalmuk százalékában

Automotive trade balance of CEE countries and the European Union, in percentage of the total automotive trade

\begin{tabular}{lrrrrrrr}
\hline Ország, országcsoport & 2001 & 2003 & 2005 & 2007 & 2008 & 2009 & 2010 \\
\hline Csehország & 28,5 & 24,6 & 31,6 & 32,0 & 31,0 & 38,8 & 40,5 \\
Lengyelország & $-10,2$ & $-12,8$ & 13,8 & 6,7 & 7,2 & 24,0 & 18,9 \\
Magyarország & 3,5 & $-7,2$ & 1,4 & 10,9 & 12,3 & 22,7 & 21,8 \\
Románia & $-49,9$ & $-42,7$ & $-48,3$ & $-46,4$ & $-39,5$ & 17,9 & 20,3 \\
Szlovákia & 16,1 & 32,2 & 18,2 & 24,7 & 22,6 & 26,8 & 26,8 \\
Szlovénia & $-1,5$ & $-3,3$ & 7,8 & 3,8 & 0,8 & 15,8 & 14,6 \\
\hline KKE-6 & 7,0 & 6,5 & 12,5 & 11,2 & 11,5 & 27,3 & 26,4 \\
EU-27 & 6,9 & 7,2 & 7,2 & 5,4 & 7,3 & 7,6 & 11,0 \\
\hline
\end{tabular}

Forrás: ITC

Európai Unió átlagát. A gazdasági recesszió hatása valamennyi vizsgált ország autóipari külkereskedelmi mérlege esetében pozitív volt, aminek hátterében általában az autóipari behozatalnak a kivitelt meghaladó arányú visszaesése állt. Miközben Csehország és Szlovákia minden évben pozitív mérleggel zárt, Románia autóipari külkereskedelme csak a recesszió kibontakozásával (exportja töretlen növekedésével és importja drasztikus csökkenésével) vált nyereségessé. A szufficitnek a termékforgalomhoz viszonyított aránya általában Csehország esetében volt a legnagyobb (3. táblázat).

Napjainkra a vizsgált hat ország - külkereskedelmi többletének az autóipari termékforgalomra vetített nagysága alapján - Európa élvonalába, közvetlenül az autóipari kivitel világranglistáját vezető, az iparág egyik innovációs motorjának számító Németország mögé került. Hozzájuk hasonló mértékű exportorientációt csak a déli periféria korábbi beruházások által erősen preferált, legnagyobbra növekedett autógyártója, Spanyolország ér el (1. ábra). A külkereskedelmi adatok tükrében is megállapítható, hogy a nyugateurópai, amerikai, ázsiai autógyártók és beszállítóik kedvelt befektetési terepévé előlépett Kelet-Közép-Európa az európai autóiparban megfigyelhető regionális átstrukturálódási folyamatok nyertese.

Kelet-Közép-Európa autóipari kivitelének és külkereskedelmi többletének dinamikus növekedése megerősíti tehát hipotézisemet, amely szerint a térség országai az elmúlt évtizedben mindinkább a termelőtevékenységek exportorientált telephelyeként jelentek meg az iparág nemzetközi munkamegosztásában. A gazdasági recesszió tovább erősítette a régió termelési profilját. Bár a felhasznált adatok - a beszállítói tevékenységek egy részének figyelembe nem vételével - vélhetően alulbecsülik az autóiparnak a térség kivitelében játszott szerepét, nem állítható, hogy a Hatok exportja kizárólag ettől az egy iparágtól függene. 
1. ábra: Az autóipar külkereskedelmének egyenlege Európa országaiban,

az összes iparági termékforgalom százalékában

Automotive trade balance in the European countries, in percentage of the total automotive trade $(2001,2008,2009,2010)$

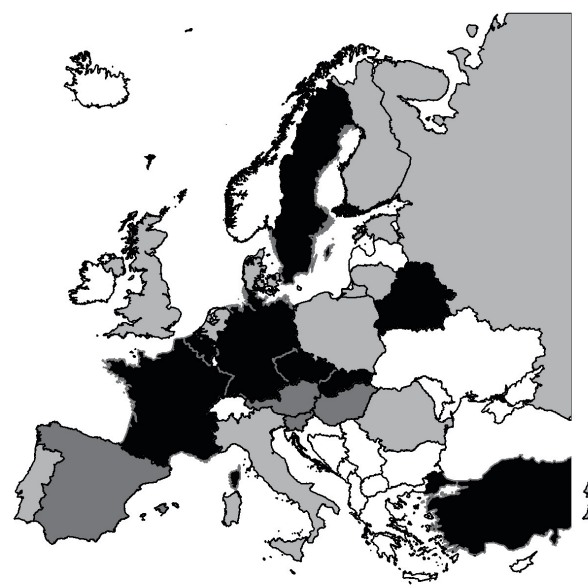

2001

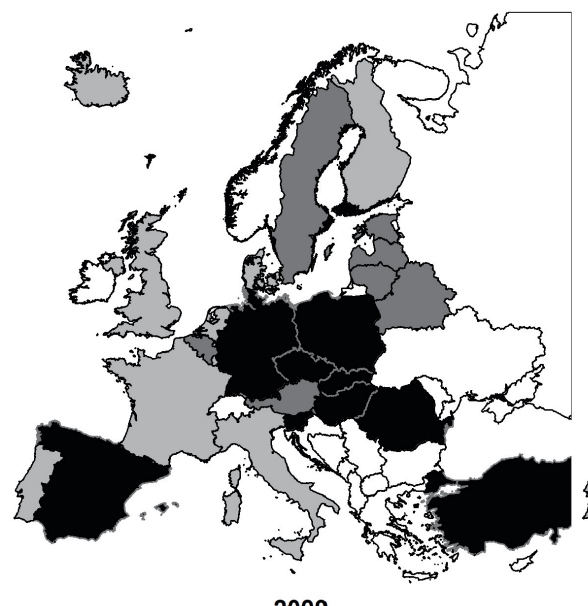

2009

JELMAGYARÁZAT

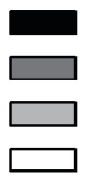

$+10 \%$ felett

$-10 \%-+10 \%$

$-50 \%--10 \%$

$-50 \%$ alatt

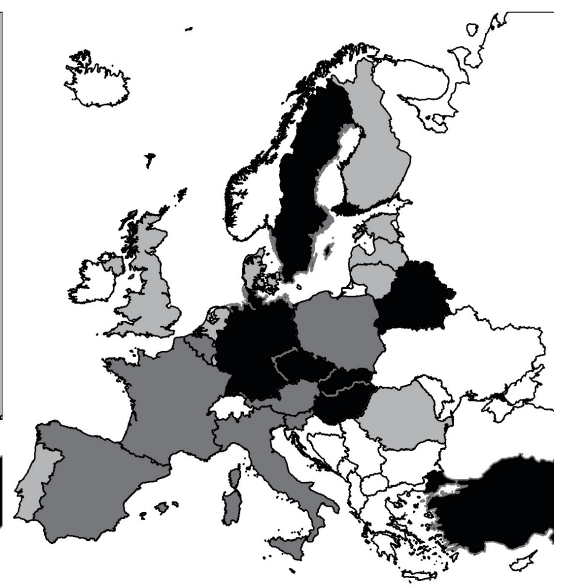

2008

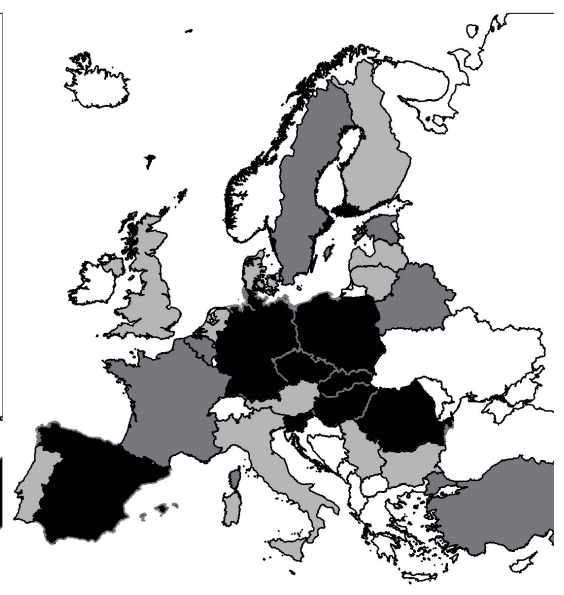

2010

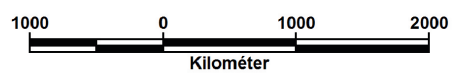

Forrás: ITC 


\section{Európára fókuszált kapcsolatrendszer, számottevő lokális relációk}

A Hatok autóipari exportjának túlnyomó része a vizsgált időszakban mindvégig az Európai Unió országaiba irányult. A piaci kapcsolatok területi diverzifikáltságának növekedésére utal ugyanakkor, hogy a recesszióig mindinkább erősödött az egymás közti és az unión kívüli európai országokkal folytatott kereskedelem, illetve mérséklődött a domináns szerepet játszó európai magterület súlya. A

4. táblázat: A Hatok autóipari kivitelének területi szerkezete (az adott relációban realizált export a teljes kivitel százalékában) és iparági kereskedelmük egyenlege Regional structure of automotive export of CEE countries (realized export in given relation, in percentage of the total export)

\begin{tabular}{|c|c|c|c|c|c|c|c|c|c|}
\hline \multirow[t]{2}{*}{ Ország } & \multirow[t]{2}{*}{ Relációk } & \multicolumn{4}{|c|}{$\begin{array}{c}\text { Exportarány, } \\
\%\end{array}$} & \multicolumn{4}{|c|}{$\begin{array}{c}\text { Külkereskedelmi mérleg } \\
\text { (az iparági termékforgalom } \\
\% \text {-ában) }\end{array}$} \\
\hline & & 2001 & 2008 & 2009 & 2010 & 2001 & 2008 & 2009 & 2010 \\
\hline \multirow[t]{4}{*}{$\overline{\mathrm{CZ}}$} & KKE-6 & 14,2 & 19,3 & 15,3 & 15,1 & 57,0 & 48,0 & 40,1 & 42,3 \\
\hline & EU & 74,4 & 67,7 & 74,5 & 71,4 & 23,0 & 26,5 & 41,4 & 41,8 \\
\hline & Európa & 6,2 & 8,2 & 5,1 & 6,7 & 91,8 & 93,4 & 90,9 & 93,2 \\
\hline & Világ & 5,2 & 4,9 & 5,0 & 6,8 & 3,3 & $-12,1$ & $-12,5$ & 0,7 \\
\hline \multirow[t]{4}{*}{$\overline{\mathrm{PL}}$} & KKE-6 & 7,6 & 9,4 & 7,6 & 7,3 & $-15,8$ & 15,1 & 4,3 & $-7,3$ \\
\hline & EU & 85,3 & 69,6 & 82,1 & 78,7 & $-7,6$ & 3,7 & 30,1 & 19,6 \\
\hline & Európa & 3,2 & 13,6 & 5,0 & 7,4 & 84,2 & 94,0 & 91,3 & 91,9 \\
\hline & Világ & 3,9 & 7,3 & 5,2 & 6,5 & $-52,7$ & $-33,2$ & $-30,9$ & 0,4 \\
\hline \multirow[t]{4}{*}{$\vec{H}$} & KKE-6 & 3,5 & 15,2 & 15,5 & 14,2 & $-41,8$ & 2,3 & 15,9 & 18,0 \\
\hline & EU & 84,9 & 71,5 & 71,8 & 68,8 & 8,5 & 10,0 & 21,3 & 15,3 \\
\hline & Európa & 3,8 & 8,6 & 6,8 & 10,0 & 51,9 & 88,4 & 85,3 & 92,2 \\
\hline & Világ & 7,8 & 4,7 & 6,0 & 7,0 & $-20,8$ & 0,8 & 12,5 & 35,1 \\
\hline \multirow[t]{4}{*}{ RO } & KKE-6 & 13,7 & 7,1 & 6,8 & 7,4 & $-17,7$ & $-71,0$ & $-35,4$ & $-26,5$ \\
\hline & EU & 58,3 & 63,4 & 75,8 & 71,7 & $-60,2$ & $-42,7$ & 22,1 & 23,0 \\
\hline & Európa & 3,4 & 12,8 & 4,5 & 6,4 & 49,5 & 74,2 & 90,4 & 92,3 \\
\hline & Világ & 24,5 & 16,7 & 13,0 & 14,5 & $-27,6$ & $-26,7$ & 30,5 & 27,3 \\
\hline \multirow[t]{4}{*}{$\overline{\text { SK }}$} & KKE-6 & 8,7 & 10,4 & 11,9 & 11,5 & $-27,9$ & $-9,3$ & $-2,6$ & $-2,3$ \\
\hline & EU & 83,1 & 63,7 & 63,8 & 59,0 & 23,0 & 24,7 & 34,4 & 34,2 \\
\hline & Európa & 5,9 & 11,0 & 11,0 & 12,4 & 95,3 & 58,3 & 24,3 & 32,0 \\
\hline & Világ & 2,2 & 14,9 & 13,3 & 17,1 & $-34,2$ & 23,9 & 28,7 & 24,7 \\
\hline \multirow[t]{4}{*}{ SLO } & KKE-6 & 4,7 & 11,3 & 6,5 & 6,9 & $-6,4$ & 16,2 & $-15,1$ & $-20,4$ \\
\hline & EU & 87,3 & 76,6 & 85,1 & 85,6 & 0,1 & 6,1 & 27,5 & 23,9 \\
\hline & Európa & 6,5 & 8,8 & 6,0 & 5,4 & 53,5 & 26,3 & 7,0 & 1,5 \\
\hline & Világ & 1,4 & 3,2 & 2,3 & 2,1 & $-71,1$ & $-68,3$ & $-63,1$ & $-50,5$ \\
\hline \multirow[t]{4}{*}{$\overline{K K E-6}$} & KKE-6 & 9,3 & 73,2 & 71,3 & 71,2 & & & & \\
\hline & $E U$ & 80,7 & 68,3 & 75,4 & 71,6 & 7,5 & 9,3 & 37,9 & 27,6 \\
\hline & Európa & 5,1 & 10,6 & 6,3 & 8,2 & 80,2 & 80,2 & 59,5 & 67,6 \\
\hline & Világ & 5,0 & 7,9 & 7,0 & 9,0 & $-27,0$ & $-14,9$ & $-4,6$ & 12,3 \\
\hline
\end{tabular}

KKE-6: a vizsgált országok csoportja; EU: a vizsgált országok csoportján kívüli EUtagállamok; Európa: az Európai Unión kivüli európai országok; Világ: az Európán kívüli államok.

Forrás: ITC 
vizsgált országok autóipari kivitelének földrajzi orientációjában jelentős különbségek mutatkoznak: Szlovákia és Románia Európán kívüli kapcsolatai mellett Csehország és Magyarország kelet-közép-európai, valamint Szlovákia és Magyarország unión kívüli európai országokba irányuló exportja említhető meg (4. táblázat).

A Hatok az Európai Unión kívüli európai országokkal folytatott kereskedelemben érték el a legnagyobb többletet, de 2010-ben az unión belüli és Európán kívüli kereskedelmük is szufficitet produkált. Iparági külkereskedelmük egyenlege elsősorban lokális, valamint Európán kívüli viszonylatban mutatott jelentős különbségeket: a szomszédokkal folytatott kereskedelem legnagyobb nyertese Csehország, míg az Európán kívüli országok Szlovákiának hozták a legtöbb jövedelmet az évtized folyamán (4. táblázat).

Németország, Olaszország és Franciaország a Hatok összességében legfontosabbnak számító autóipari külkereskedelmi partnere. Jellemző, hogy a recesszióig valamennyi régióbeli ország esetében csökkent e három exportpiac együttes súlya. Az évtized folyamán a domináns szerepet játszó Németország (és kisebb mértékben Olaszország) szerepének halványodása, illetve Franciaország mérsékelt erősödése figyelhető meg. A három országgal lebonyolított külkereskedelem többlete növekedett, a korábban regionális szinten is veszteséggel záró francia reláció szufficitessé vált. Az évtized végén valamennyi vizsgált kelet-közép-európai ország kiemelt partnerekkel folytatott kereskedelmében többlet mutatkozott (5. táblázat).

5. táblázat: Németország, Franciaország és Olaszország részesedése a Hatok autóipari kiviteléből, illetve az iparági kereskedelem egyenlege

Shares of Germany, France and Italy in the automotive exports of CEE countries, and automotive trade balance in these relations

\begin{tabular}{|c|c|c|c|c|c|c|c|c|}
\hline \multirow{2}{*}{$\begin{array}{c}\text { Ország, } \\
\text { országcsoport }\end{array}$} & \multicolumn{4}{|c|}{2001} & \multicolumn{4}{|c|}{2010} \\
\hline & $\begin{array}{l}\text { Német- } \\
\text { ország }\end{array}$ & $\begin{array}{l}\text { Francia- } \\
\text { ország }\end{array}$ & $\begin{array}{l}\text { Olasz- } \\
\text { ország }\end{array}$ & Összesen & $\begin{array}{l}\text { Német- } \\
\text { ország }\end{array}$ & $\begin{array}{l}\text { Francia- } \\
\text { ország }\end{array}$ & $\begin{array}{l}\text { Olasz- } \\
\text { ország }\end{array}$ & Összesen \\
\hline & \multicolumn{8}{|c|}{ Exportarány, \% } \\
\hline Csehország & 35,6 & 5,8 & 5,4 & 46,7 & 31,1 & 8,9 & 4,1 & 44,1 \\
\hline Lengyelország & 42,3 & 5,5 & 21,1 & 68,9 & 27,8 & 8,6 & 16,2 & 52,6 \\
\hline Magyarország & 61,7 & 2,1 & 5,2 & 68,9 & 38,3 & 3,9 & 6,8 & 49,0 \\
\hline Románia & 39,0 & 3,8 & 7,1 & 49,9 & 24,4 & 20,8 & 7,1 & 52,3 \\
\hline Szlovákia & 43,1 & 7,4 & 13,9 & 64,4 & 22,2 & 12,2 & 5,3 & 39,8 \\
\hline Szlovénia & 31,6 & 27,2 & 18,0 & 76,8 & 20,1 & 35,8 & 8,6 & 64,5 \\
\hline \multirow[t]{2}{*}{ KKE-6 } & 42,7 & 6,8 & 71,0 & 60,6 & 28,4 & 71,0 & 8,4 & 47,9 \\
\hline & \multicolumn{8}{|c|}{ Egyenleg, \% } \\
\hline Csehország & 12,7 & 0,6 & 45,4 & 13,9 & 26,8 & 47,1 & 37,6 & 31,4 \\
\hline Lengye & $-2,1$ & $-51,0$ & 33,9 & $-1,8$ & 2,2 & 28,2 & 43,3 & 16,3 \\
\hline Magyarország & 23,7 & $-62,0$ & $-7,7$ & 13,1 & 4,5 & 11,8 & 52,6 & 9,8 \\
\hline Románia & $-54,3$ & $-69,9$ & $-58,8$ & $-56,7$ & 16,5 & 40,4 & 24,4 & 26,1 \\
\hline Szlovákia & 11,4 & 27,1 & 75,4 & 22,8 & 8,2 & 47,8 & 55,4 & 23,4 \\
\hline Szlovénia & 11,3 & $-14,0$ & 25,1 & 3,2 & 9,5 & 50,6 & $-1,3$ & 26,9 \\
\hline KKE-6 & 9,0 & $-23,1$ & 32,7 & 7,4 & 71,8 & 40,3 & 40,1 & 21,8 \\
\hline
\end{tabular}

Forrós: ITC 
A három kiemelt partner jelentőségének hátterében autóipari vállalataiknak a régióban mutatott aktivitása áll. A „kvázi-integrált” európai piacra termelő autóipari szereplők esetében ugyanis általában kiemelkedő az anyaország fogyasztópiacként játszott szerepe (Schamp 2005). Így nemcsak az alkatrészgyártás, hanem az összeszerelő tevékenységek kapcsán is kijelentheto", hogy egy adott cég beruházása általában anyaországa piacának jelentőség-növekedését eredményezi. A német reláció (VW-csoport, GM-Opel) dominanciáján túl a lengyel-olasz kapcsolatok intenzitására a Fiat, a szlovén-francia kereskedelem fontosságára a Renault tevékenysége a magyarázat (Szlovénia az egyetlen ország a régióban, amelynek nem Németország, hanem Franciaország a vezető exportpiaca ebben az iparágban). Franciaország súlyának számottevő növekedése a térségben megvalósított francia tőkebefektetések (Renault: Románia; PSA: Csehország és Szlovákia) hatásaival magyarázható.

2001 és 2008 között a Hatok egymás között lebonyolított autóipari exportja 1,5 milliárd euróról 7,5 milliárd euróra növekedett, majd 2009-ben erős visszaesés, a kapcsolatok intenzitásának csökkenése következett. Figyelemre méltó a legfontosabb kereskedelmi relációk stabilitása: a legnagyobb volumenű kivitel mindvégig Csehországból Szlovákiába, illetve Csehországból Lengyelországba irányult. Az évtized folyamán mérséklődött ugyanakkor a régión belüli exportkapcsolatok koncentráltsága: a tíz vezető viszonylat aránya $85 \%$-ról $75 \%$ alá csökkent. A kapcsolatok nagyságrendje alapján három jól körülhatárolható csoport rajzolódik ki a régióban. Csehországhoz külön-külön igen intenzív kapcsolatok füzik mind Lengyelországot, mind Szlovákiát (első kör). Viszonylag jelentős Magyarország kereskedelme a három másik visegrádi országgal (második kör). Végül, jóval kisebb volumenű kapcsolatok alakultak ki Románia és Szlovénia, illetve a visegrádi országok között (harmadik kör). Magyarország és Csehország Romániába irányuló exportja ugyanakkor látványosan növekedett az elmúlt években, Magyarország számára a román reláció vált az egyik legfontosabbá (2. ábra).

Az egymás közötti kapcsolatok felértékelődésében egyrészt szerepet játszott az ezredforduló után jelentős gazdasági növekedést mutató régió országainak megnövekedett autófogyasztása. Másrészt, az autóipari értékláncokat irányító transznacionális vállalatok stratégiái nyomán az elmúlt években számos, vezető autógyártók vagy beszállítók által végzett tevékenység épült ki újonnan, vagy települt át az anyaországokból Kelet-Közép-Európába, erősítve a periféria-periféria-relációt a centrum-periféria-kapcsolatokkal szemben.

Összegzésként megállapítható, hogy a térség országainak autóipara főként az európai kontinens piacára termel, és napjainkban mind az EU, mind Európának az unión kívüli országai felé viszonylag egyveretű többletet mutat. KeletKözép-Európa szempontjából egyrészt fontos - bár összességében mérséklődő szerepe van a nagy autóipari befektetők anyaországaihoz (főként Németországhoz) füződő kapcsolatoknak, másrészt a régió belső nexusainak szerepe hosszabb távon jelentős növekedést, illetve stabilnak tűnő régión belüli térszer- 
2. ábra: A Hatok egymás közti autóipari kereskedelmének változása Changes in mutual automotive trade of CEE countries
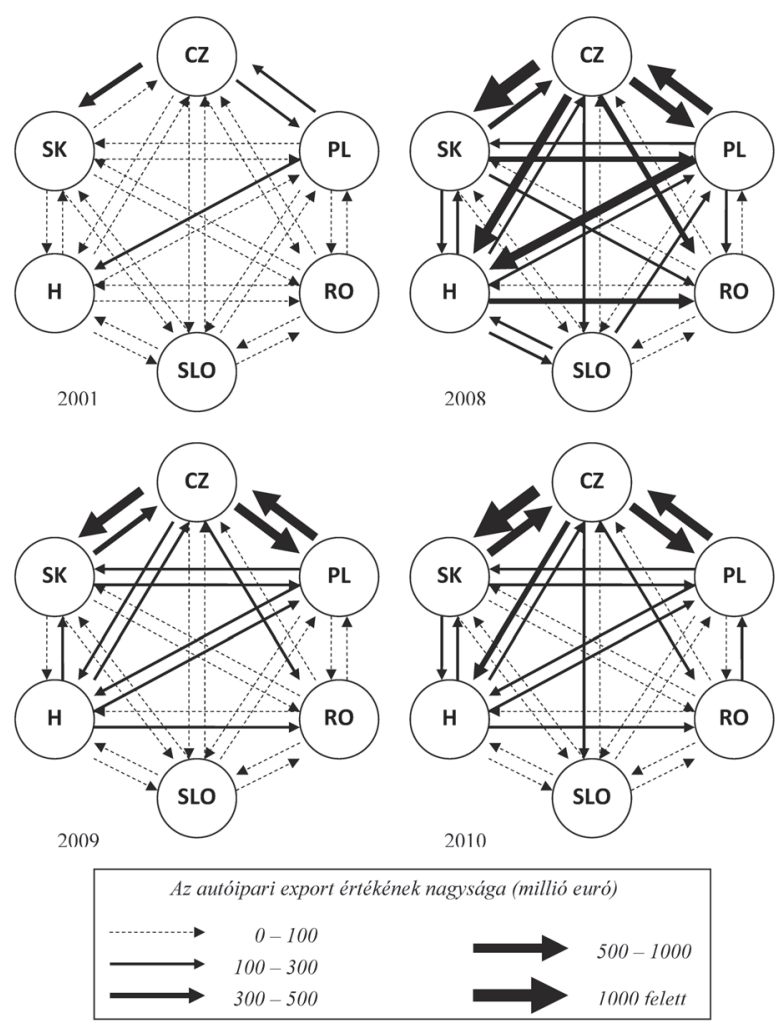

Forrás: ITC

kezetet mutat. A legintenzívebb kapcsolatok Csehország és közvetlen szomszédai között alakultak ki.

\section{Személygépkocsi-összeszerelő́k és gépjármúalkatrész-beszállítók}

A közúti jármügyártás meglehetősen heterogén termékcsoportján belül világviszonylatban és a Hatok esetében is a személygépkocsik, illetve a gépjármü-alkatrészek exportja játszik meghatározó szerepet. Kelet-Közép-Európa kivitelében ugyanakkor nagyobb a gépjármü-alkatrészek és kisebb az „egyéb termékek” (buszok, tehergépjármüvek, motorkerékpárok stb.) részaránya. A két fő termékcsoport (személygépjárművek és gépjárműalkatrészek) egymáshoz viszonyított kiviteli arányában némi eltolódás - a globális és európai trendeknek megfelelően - a Hatok 
6. táblázat: Az autóipari kivitel termékszerkezete Kelet-Közép-Európa vizsgált országaiban (†ermékek az összes iparági export értékének százalékában)

Product structure of automotive export in CEE countries

(different goods in percentage of the total automotive export)

\begin{tabular}{lccc|ccc}
\hline Ország, térség & \multicolumn{3}{c|}{2001} & \multicolumn{3}{c}{2010} \\
\cline { 2 - 7 } & $\begin{array}{c}\text { Személy- } \\
\text { gépjármú- alkatrészek } \\
\text { vek }\end{array}$ & $\begin{array}{c}\text { Gépjérmúb } \\
\text { termé- } \\
\text { kek }\end{array}$ & $\begin{array}{c}\text { Személy- } \\
\text { gépjármú- } \\
\text { vek }\end{array}$ & $\begin{array}{c}\text { Gépjármú- } \\
\text { alkatrészek }\end{array}$ & $\begin{array}{c}\text { Egyéb } \\
\text { termé- } \\
\text { kek }\end{array}$ \\
\hline Csehország & 55 & 36 & 9 & 56 & 38 & 7 \\
Lengyelország & 44 & 32 & 25 & 44 & 37 & 19 \\
Magyarország & 54 & 33 & 13 & 50 & 39 & 11 \\
Románia & 27 & 57 & 16 & 44 & 44 & 12 \\
Szlovákia & 74 & 20 & 6 & 70 & 18 & 13 \\
Szlovénia & 68 & 20 & 12 & 73 & 17 & 9 \\
\hline KKE-6 & 56 & 31 & 13 & 54 & 34 & 12 \\
EU-27 & 60 & 22 & 19 & 56 & 26 & 18 \\
Világ & 56 & 24 & 20 & 52 & 27 & 21 \\
\hline
\end{tabular}

Forrós: ITC

esetében is a gépjárműalkatrészek exportja felé történt, ami az iparágon/vállalaton belüli nemzetközi munkamegosztás elmélyülésére utal (6. táblázat).

A két legfontosabb árucsoport kiviteli értékének egymáshoz viszonyított aránya alapján kijelenthető, hogy Kelet-Közép-Európa a vizsgált évtizedben, a legtöbb relációban elsősorban személygépkocsi-exportőrként jelent meg (7. táblázat), s ezt a tendenciát a gazdasági recesszió átmenetileg erősítette is. Feltűnő, hogy a vizsgált évtizedben az Európán belülre irányuló kivitelben növekedett, míg a távolabbi világrészek felé kiszállított termékek körében csökkent a gépjárműalkatrészek aránya. Az alkatrészek részesedése a vizsgált országok egymás közti kereskedelmében volt a legnagyobb az évtized végén. Ezek a tények az elmélyülőben lévő iparágon/vállalaton belüli nemzetközi munkamegosztás regionális (kontinentális)

7. táblázat: A személygépkocsik és a gépjármúalkatrészek kiviteli értékének aránya országonként, különböző területi relációkban

Rates of cars to motor vehicle parts within the export of CEE countries, in different territorial relations

\begin{tabular}{lrrrr|rrrr}
\hline \multicolumn{1}{c}{ Ország, } & \multicolumn{4}{c|}{2001} & \multicolumn{4}{c}{2010} \\
\cline { 2 - 9 } országcsoport & KKE-6 & EU & Európa & Világ & KKE-6 & EU & Európa & Világ \\
\hline Csehország & 1,63 & 1,37 & 11,12 & 1,34 & 0,90 & 1,56 & 3,94 & 1,06 \\
Lengyelország & 1,31 & 1,40 & 0,70 & 1,76 & 0,24 & 1,37 & 1,55 & 1,02 \\
Magyarország & 0,28 & 2,03 & 2,85 & 0,07 & 1,54 & 1,12 & 4,66 & 0,84 \\
Románia & 1,46 & 0,01 & 7,16 & 3,30 & 0,38 & 1,20 & 0,72 & 0,82 \\
Szlovákia & 1,21 & 4,10 & 25,14 & 1,32 & 1,64 & 3,45 & 4,76 & 25,39 \\
Szlovénia & 26,54 & 3,38 & 1,78 & 0,00 & 1,11 & 5,22 & 2,99 & 1,31 \\
\hline KKE-6 & 1,42 & 1,82 & 4,78 & 0,84 & 0,86 & 1,65 & 2,85 & 1,97 \\
\hline
\end{tabular}

KKE-6: a vizsgált országok csoportja; EU: a vizsgált országok csoportján kívüli EUtagállamok; Európa: az Európai Unión kivüli európai országok; Világ: az Európán kívüli államok.

Forrás: ITC 
dimenziójára, illetve egy ezen belül formálódó lokális autóipari munkamegosztásra utalnak.

A vizsgált országok kivitelének termékszerkezete komoly különbségeket mutat (7. táblázat). Az egyik pólust Szlovákia képviseli, amely minden relációban személygépkocsi-exportőrként jelent meg („összeszerelő” profil). Az ellenpólus Románia, amelynek kivitelében általában a gépjárműalkatrészek dominanciája érvényesült („,beszállító” profil). Fontos látni ugyanakkor, hogy a gépjármüalkatrészeknek az exportban játszott szerepe keveset mond az alkatrészgyártás tényleges jelentőségéről, hiszen egyrészt az összeszerelt személygépkocsik számottevő mennyiségben tartalmazhatnak helyben gyártott alkatrészeket, másrészt a beépített helyi alkatrészek aránya gyártónként és országonként komoly eltéréseket mutat (Sass, Szanyi 2004, Kemenczei, Nikodémus 2006, Pavlinek, Domanski, Guzik 2009).

Figyelemre méltó, hogy a Hatok Németországba irányuló kivitele a gépjármüalkatrészek irányába tolódott az évtized folyamán, s e termékcsoport - elsősorban Románia, Csehország és Lengyelország exportjának alkatrész-orientáltsága miatt - ebben a relációban dominánssá is vált. Franciaország és Olaszország inkább a személygépkocsi-kivitel felvevőpiaca, ráadásul a francia relációban növekedett is e termékcsoport jelentősége (8. táblázat). Vélhetően a vezető európai autópiacokon bevezetett roncsprémiumnak a térségben gyártott autók fogyasztására gyakorolt pozitív hatása, illetve a krízis idején visszaeső autógyártás által generált kisebb alkatrészigény nyomán 2009-ben a térség kivitelének szerkezete mindhárom ország esetében a személygépkocsi-export felé tolódott.

A kelet-közép-európai régión belüli kereskedelemben a gépjárműalkatrészek irányába eltolódó viszonylatok növekvő száma jellemző. 2001-ben a kapcsolatok 40\%-a, 2009-2010-ben mintegy 60\%-a mutatott gépjármüalkatrész-többletet. 2008-ig a személygépkocsi-kivitelhez képest nagyobb arányú növekedés, 2009-ben kisebb mértékű visszaesés jellemezte a régión belüli gépjár-

8. táblázat: A személygépkocsik és a gépjármúalkatrészek kiviteli értékének aránya országonként, különböző területi relációkban

Rates of cars to motor vehicle parts within the export of CEE countries, in different territorial relations

\begin{tabular}{|c|c|c|c|c|c|c|c|c|}
\hline \multirow{2}{*}{$\begin{array}{c}\text { Ország, } \\
\text { országcsoport }\end{array}$} & \multicolumn{4}{|c|}{2001} & \multicolumn{4}{|c|}{2010} \\
\hline & $\begin{array}{l}\text { Német- } \\
\text { ország }\end{array}$ & $\begin{array}{c}\text { Francia- } \\
\text { ország }\end{array}$ & $\begin{array}{l}\text { Olasz- } \\
\text { ország }\end{array}$ & Összesen & $\begin{array}{l}\text { Német- } \\
\text { ország }\end{array}$ & $\begin{array}{c}\text { Francia- } \\
\text { ország }\end{array}$ & $\begin{array}{l}\text { Olasz- } \\
\text { ország }\end{array}$ & Összesen \\
\hline Csehország & 0,64 & 0,82 & 10,81 & 0,84 & 0,74 & 1,53 & 7,94 & 1,01 \\
\hline Lengyelország & 0,97 & 0,79 & 3,65 & 1,5 & 0,63 & 1,06 & 5,31 & 1,27 \\
\hline Magyarország & 2,50 & 1,27 & 3,38 & 2,5 & 0,95 & 1,78 & 2,48 & 1,14 \\
\hline Románia & 0,00 & 0,30 & 0,01 & 0,01 & 0,41 & 4,38 & 2,28 & 1,19 \\
\hline & 2,2 & 19,86 & 47,23 & 3, & 1, & 6,60 & 11,67 & 2,71 \\
\hline Szlover & 2,37 & 6,27 & 6,56 & 4,0 & 1,84 & 13,24 & 3,33 & 4,86 \\
\hline KKE-6 & 1,27 & 2,17 & 5,71 & 1,70 & 0,78 & 2,61 & 5,06 & 7,38 \\
\hline
\end{tabular}

KKE-6: a vizsgált országok csoportja; EU: a vizsgált országok csoportján kívüli EUtagállamok; Európa: az Európai Unión kivüli európai országok; Világ: az Európán kívüli államok.

Forrás: ITC 
3. ábra: A Hatok egymás közti kereskedelmének termékszerkezet-változása a személygépkocsi-export gépjármúalkatrész-kivitelhez viszonyított értékaránya alapján

Changes in product structure of mutual automotive trade of CEE countries, based on the rates of cars to motor vehicle parts within the export
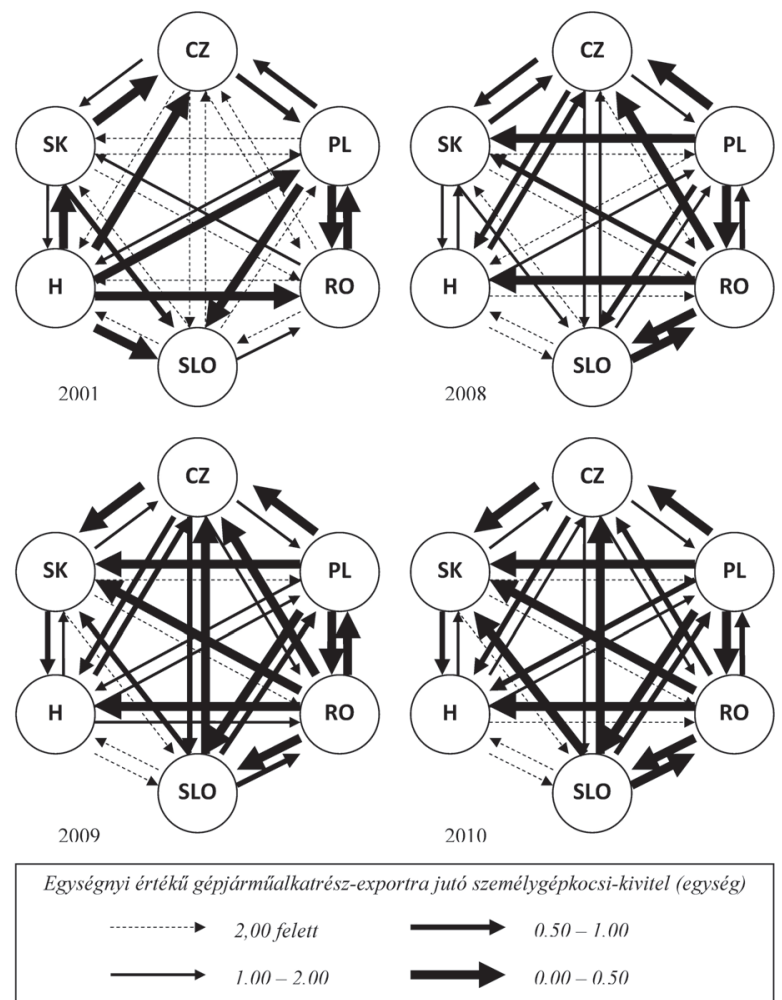

Forrás: ITC

müalkatrész-exportot, amelynek értéke 2010-ben nagyobb volt, mint korábban bármikor. Jellemző, hogy az évtized folyamán más-más országok relációjában jelentek meg azok a viszonylatok, amelyek esetében a gépjárműalkatrészek kivitele dominál. Kezdetben a legtöbb ilyen viszonylat kiindulópontja Magyarország volt, majd Lengyelország és Románia kivitele tolódott el erősen a gépjármüalkatrészek irányába. A krízis nyomán Románia exportja minden régión belüli relációban gépjárműalkatrész-orientálttá vált, de Szlovénia külkereskedelmében is jelentős átrendeződés történt a személygépkocsi-export rovására. A lengyel-cseh reláció volt az egyetlen olyan fontosabb külkereskedelmi kapcsolat a régióban, amely mindvégig gépjármüalkatrész-dominanciát mutatott (3. ábra).

Kelet-Közép-Európa autóipari exportszerkezetében ugyan világátlagot meghaladó mértékű a gépjárműalkatrészek aránya, ez azonban nem változtat 
azon a tényen, hogy a térség inkább személygépkocsi-exportőrként jelenik meg a nemzetközi munkamegosztásban. E megállapítás éppen a legfontosabb piacnak számító Németországra nem érvényes, ami a vezető európai autógyártó irányába formálódó beszállítói szerepre utal. Kelet-közép-európai relációban a gépjárműalkatrészek exportja összesített arányában és a dominált relációk számában is növekedést mutat, s ez elmélyülő lokális munkamegosztást sugall. Hipotézisem tehát ebben az esetben is igazolódni látszik: a gépjármüalkatrészek exportban játszott szerepe meghaladja a világátlagot, és - alárendeltsége ellenére is - komoly aránynövekedést produkál bizonyos viszonylatokban. A Hatok nemzetközi munkamegosztásba történő bekapcsolódása jelentős időbeli változásokat és egymáshoz képest megfigyelhető különbségeket mutat.

\section{Összegzés}

Kelet-Közép-Európa a transznacionális szereplők által meghatározott autóipar exportorientált termelő telephelye. Gépjármügyártása egy európai termelési és fogyasztási rendszer részeként müködik, elsősorban Németországhoz füzik erős kapcsolatok. Autóipari kivitelének termékszerkezet-változása iparágon belüli elmélyülő nemzetközi munkamegosztásra utal, ami elsősorban a német relációban, valamint az egymás közti kereskedelemben haladt előre. Az autóipari export adataira épített vizsgálat eredményei (az iparág komoly koncentrációja, a növekvő jelentőségű helyi kapcsolatrendszer, az intenzívebbé váló iparágon/vállalaton belüli munkamegosztás a régióban) alapján - részben - a tanulmány elején megfogalmazott negyedik hipotézisre is pozitív válasz adható. Kelet-Közép-Európa az elmúlt évtizedben előrelépett az autóipari körzetté formálódás útján, de függőségi viszonyai miatt inkább tekinthető egy Németországot is felölelő körzet keleti részének, mintsem önálló egységnek.

\section{Irodalom}

Dicken, P. (2011): Global Shift. Mapping the Changing Contours of the World Economy. Sage, Los Angeles, London, New Delhi, Singapore, Washington D. C.

Jürgens, U., Krzywdzinski, M. (2009): Changing East-West division of labour in the European automotive industry. European Urban and Regional Studies, 1., 27-42.

Kemenczei N., Nikodémus A. (2006): Autóipari trendek a nagyvilágban és hazánkban. Külgazdaság, 3., 57-66.

Molnár E. (2009): A világ autóiparának változó földrajza. Földrajzi Közlemények, 2., 105-120.

Pavlinek, P., Domanski, B., Guzik, R. (2009): Industrial upgrading through foreign direct investment in Central European automotive manufacturing. European Urban and Regional Studies, 1., 43-63.

Sass M., Szanyi M. (2004): A hazai cégek és a multinacionális vállalatok közötti beszállítói kapcsolatok alakulása. Külgazdaság, 9., 4-22.

Schamp, E. W. (2005): Die Autoindustrie auf dem Weg nach Europa. Zur Integration nationaler 
Standortsysteme der Autoproduktion. Geographische Rundschau, 12., 12-19.

Sturgeon, T., Van Biesebroeck, J., Gereffi, G. (2008): Value chains, networks and clusters: reframing the global automotive industry. Journal of Economic Geography, 8., 297-321.

http://eprints.ucl.ac.uk/17517/1/17517.pdf (Radosevic, S., Rozeik, A. (2005) Foreign direct investment and restructuring in the automotive industry in Central and East Europe. University College London, Centre for the Study of Economic and Social Change in Europe) Letöltés: 2011. dec. 20.

http://www.unido.org/fileadmin/media/documents/pdf/Services_Modules/Automotive_Industry.pdf (Humphrey, J., Memedovic, O. (2003): The global automotive industry value chain: what prospects for upgrading by developing countries. UNIDO, Vienna) Letöltés: 2011. aug. 1.

http://www.trademap.org/tradestat/Country_SelProduct_TS.aspx (International Trade Centre/Nemzetközi Kereskedelmi Központ közúti jármügyártásra vonatkozó export- és import- adatai) Letöltés: 2011. nov. 30. 


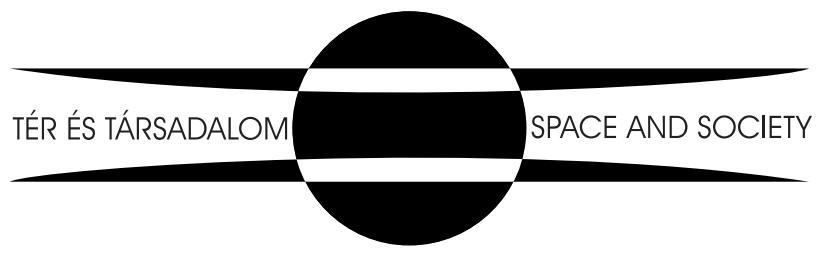

